\title{
Nutritional and Organoleptic Properties of Wheat (Triticum aestivum) and Beniseed (Sesame indicum) Composite Flour Baked Foods
}

\author{
Christine Emmanuel-Ikpeme ${ }^{1}$, Christopher Eneji ${ }^{2} \&$ Godwin Igile ${ }^{1}$ \\ ${ }^{1}$ Biochemistry Department, University of Calabar, Nigeria \\ ${ }^{2}$ Dept. of Animal Science, University of Calabar, Nigeria \\ Correspondence: Christine Emmanuel-ikpeme, Biochemistry Department, University of Calabar, Calabar, Cross \\ River State, Nigeria. Tel: 234-703-821-8884. E-mail: christineikpeme@yahoo.com
}

Received: March 5, 2012 Accepted: March 20, 2012 Online Published: May 29, 2012

doi:10.5539/jfr.v1n3p84 URL: http://dx.doi.org/10.5539/jfr.v1n3p84

\begin{abstract}
Eating snacks during lunch periods has become a way of life for school children and the busy working class people in most urban cities in developing nations like Nigeria. Providing nutritious and healthy snacks remains a major challenge for the food industry to tackle, including the issue of sugar and carbohydrate contents in snacks which predisposes obesity. Nutritional and sensory characteristics of baked foods produced from wheat/beniseed flour composite were investigated with the aim of producing healthy and nutritious baked foods. Beniseed was substituted in wheat flour so as to increase the protein content and enhance the nutritive value of baked food produced from such composite flour. Beniseed was substituted in wheat flour at 3 levels $(10 \%, 20 \%, 30 \%)$ with other ingredients to produce bread and cake. The samples were analyzed for proximate content, vitamin A and C, antinutrients, minerals and sensory properties. Proximate and mineral contents, as well as Vitamin A and C content of the bread and cake showed significant increases $(\mathrm{P}>0.05)$ with increase in beniseed substitution levels. The level of total oxalate and soluble oxalate significantly increased $(\mathrm{P}<0.05)$, while phytate and tannins significantly $(\mathrm{P}<0.05)$ decreased with increase in beniseed substitution level. There was no significant difference $(\mathrm{P}<0.05)$ in the panelist ratings for taste, color, flavor, texture and overall acceptability of $10 \%$ beniseed substitution for bread and up to $20 \%$ beniseed substitution for cake with the control. The results indicate that a healthy and nutritious snack could be produced from wheat and beniseed flour composite. This study is of public health significance in Nigeria.
\end{abstract}

Keywords: snacks, beniseed, composite flour, antinutrients, Vitamins

\section{Introduction}

Bread has been a major component of human diet dating back to pre-historic man, making the baking of yeast leavened and sour dough bread one of the oldest biotechnological processes. Wheat is unique among other grains because of its content of gluten protein. The unique properties of wheat protein produce bread of low weight and high strength and elasticity as well as desirable texture and flavor (Nickerson, 1980). The major source of flour for products such as bread, biscuits, chin-chin, meat pie and cake is wheat flour. Wheat flour as the major ingredient for bakery products has dominated other potential sources of flour for bakery products. However, the high cost of wheat flour has led to a rise in the cost of bakery products in Nigeria and indeed other countries in Sub-Sahara Africa.

Effort is being made to find alternative sources of flour for supplementing wheat flour and also for improving the nutritional value of baked products. This has resulted in the need to source locally available and underutilized crops such as beniseed (Sesame indicum). This would drive down cost, enhance affordability by low-income populations and improve the nutritive value of baked products.

Sesame (Sesamum indicum L.) belongs to the Pedaliaceae family of plants and it is cultivated in several countries including the USA, India, China, Burma, Sudan and Nigeria (Abou-Garbia et al., 2000). The seed is high in edible oil, protein and calcium and has been used as food for ages (Hui, 1996). In Nigeria, the seeds are fried or used to produce soup for human consumption (Alobo, 2001; Abu-Jdayil et al. 2002). Uaboi et al., (2008) suggested that fermented Sesame seeds could be used as a soup condiment. Sesame has been valued as a healthy food additive preventing diseases and promoting well being. Its nutraceutical uses include cancer prevention 
(Myristic acid), prevention of heart disease (Sesame) and antioxidant, hepatoprotective (lecithin) (www.whfoods.com/genpage.php). Sesame seed consumption appears to increase plasma gamma-tocopherol and enhanced a vitamin E activity which is believed to prevent cancer and heart disease (Cooney et al., 2001).

In addition sesame seeds contain two unique substance, sesamin and sesamolin which belong to a group of special beneficial fibers called ligrians, and have been shown to have a cholesterol lowering effects in humans. It also prevents high blood pressure and increase vitamin E supplies in animals. Sesamin has been found to protect the liver from oxidative damage. Sesame seed phytosterols reduce cholesterol, enhance the immune response and decrease risk of certain cancers (www.whfoods.com/genpage.phy).

Afolabi et al. (2001) showed that the bread produced from wheat, beniseed and cassava composite flour had similar baking characteristics in terms of appearance, color and flavor when compared with white wheat bread with higher protein and fat contents. However, raw sesame seeds contain anti-nutrients like oxalate and phytate, which are found in the seed hull (Akonji et al., 2003). These substances can adversely affect mineral bioavailability in human nutrition (Van de Poal, 1990). The evaluation of baked foods produced from beniseed and wheat flour has not yet been fully elucidated. For this reason, it becomes important to investigate the nutritional and sensory characteristics of these foods, aiming at possible product commercialization.

\section{Materials and Method}

\subsection{Materials}

The experimental materials consisting of beniseed (Sesamum indicum) and wheat flour were purchased from a local market in Calabar, Cross River State, Nigeria. All chemical reagents of analytical grade were purchased from Sigma Aldrich (Germany).

\subsection{Preparation of Beniseed Flour and Composite Flour}

Beniseed were destoned and washed thrice with portable tap water, and then dried in an oven at $105^{\circ} \mathrm{C}$ for $6 \mathrm{~h}$. The dried grains were milled in a laboratory type hammer mill (Christy Type) to pass through a $250 \mu \mathrm{m}$ mesh sieve and then packaged in an air tight container for storage until used. Three composite flour samples were formulated from wheat and beniseed flours in the ratios of 70:30; 80:20; and 90:10 respectively.

\subsection{Preparation of Baked Food}

Bread and cake samples were produced from the three composite flour samples. In bread making, "Rubbin in" method was used in a Hobart precipitate 404 Dough Mixer. All ingredients (Composite flour 700g, water 200ml, sugar $80 \mathrm{~g}$, salt $5 \mathrm{~g}$, fat $30 \mathrm{~g}$ ( $40 \mathrm{~g}$ of fat for $90: 10$ ratio), yeast $50 \mathrm{~g}$ and full cream milk powder $20 \mathrm{~g}$ were mixed in the dough mixer. Sugar $(100 \mathrm{~g})$ and $50 \mathrm{~g}$ of fat were used in the control. The mixture was then put into the baking pan of the bread machine and kneaded manually for $10 \mathrm{~min}$ at $43^{\circ} \mathrm{C}$, allowed for $40 \mathrm{~min}$ to rise followed by 2 minutes of punching and leveling of the dough. The procedure was repeated three times and the dough baked for 35 minutes at $235^{\circ} \mathrm{C}$ in the Oven. Bread sample was produced from $100 \%$ white wheat flour as control.

The ingredients used for cake production were; composite flour $500 \mathrm{~g}$, fat $50 \mathrm{~g}$, sugar $110 \mathrm{~g}$, whole egg 3 , vanilla $10 \mathrm{ml}$, baking powder $5 \mathrm{~g}$; full cream milk powder $20 \mathrm{~g}$, while $150 \mathrm{~g}$ of sugar was used for the control. The margarine was creamed with sugar until soft and light, and eggs were beaten into the flour. Creaming continued for about 15 min and then mixed (Philip Sc. 300) until a dropping consistency was achieved, and then baked in a greased tin for approximately $1 \frac{1 / 4}{4}$ hours at $181^{\circ} \mathrm{C}$ temperature. Cake sample was also produced from $100 \%$ white wheat sample as control.

\subsection{Analysis}

Moisture, crude protein, crude fibre and ash contents were determined by the methods of AOAC (2005). Carbohydrate was determined by difference. Vitamin A was determined by the spectrophotometric method of Thompson et al. (2010). Titration method of Kiok and Sawyer (1991) was used to determine vitamin C. The method of AOAC (1990) was used to determine sodium, potassium, calcium, phosphorus and magnesium. Phytate content was determined by the method of Nkama and Gbenyi (2001), while oxalates were determined by the method of Day and underwood (1986). Tannic content was estimated by the method of Hoff and Singleton (1977).

\subsection{Sensory Evaluation}

The method of Larmond (1977) was used for sensory evaluation. The samples of bread and cake were subjected to sensory evaluation with $100 \%$ white wheat flour bread (100\% WWFB) and cake (100\% WWFC) as control. A nine member experienced panelists drawn from Biochemistry Department, University of Calabar were used to evaluate the samples. The panelists rated the samples twice in a random order for colour, smell, flavor, taste, 
texture, and overall acceptability using 9-point hedonic scale, where I was extremely acceptable and 9 was extremely unacceptable. Room temperature water and unsalted crackers were given to the panelists for mouth rinsing between samples after to eliminate carry over effects.

\subsection{Statistical Analysis}

All experiments including organoleptic analyses were repeated in 3 sets independently and each having 3 replicates. The means and standard deviations (SD) were calculated taking all the readings in consideration. Statistical analysis was performed using SPSS (Statistical Package for Social Sciences). One way ANOVA (Analysis of variance at the level of significance $\mathrm{P} \leq 0.05$ ) was performed using Duncan multiple range test to ascertain the significance of the means.

\section{Results}

\subsection{Proximate Composition}

The results of the proximate composition are shown in Table 1. Protein and fat contents of 70/30 ratio bread sample was significantly $(\mathrm{P}<0.05)$ highest with values of $16.44 \pm 0.02 \%$ and $15.40 \pm 0.2 \%$ respectively. The sample with the least protein content was the control $(8.30 \pm 0.14 \%)$. Bread samples made from the composite flour had significantly higher protein content. A similar trend was observed for cake. The 70/30 sample showed significantly higher values for proximate principles.

Table 1. Proximate composition of bread and cake produced from wheat/beniseed composite flour (percent)

\begin{tabular}{|c|c|c|c|c|c|c|c|c|}
\hline \multirow[b]{2}{*}{ Parameter } & \multicolumn{4}{|c|}{ Bread } & \multicolumn{4}{|c|}{ Cake } \\
\hline & $70 / 30$ & $80 / 20$ & $90 / 10$ & Control & $70 / 30$ & $80 / 20$ & $90 / 10$ & Control \\
\hline Moisture & $11.09 \pm 0.02^{\mathrm{a}}$ & $8.35 \pm 0.10^{b}$ & $7.28 \pm 0.04^{\mathrm{c}}$ & $5.13 \pm 0.12^{\mathrm{d}}$ & $2.15 \pm 0.15^{\mathrm{a}}$ & $1.51 \pm 0.13^{\mathrm{b}}$ & $1.32 \pm 0.12^{\mathrm{c}}$ & $1.11 \pm 0.06^{\mathrm{d}}$ \\
\hline Ash & $1.93 \pm 0.01^{\mathrm{a}}$ & $1.50 \pm 0.14^{b}$ & $1.25 \pm 0.10^{\mathrm{c}}$ & $1.13 \pm 0.20^{\mathrm{d}}$ & $1.40 \pm 0.14^{\mathrm{a}}$ & $1.33 \pm 0.09^{\mathrm{b}}$ & $1.10 \pm 0.04^{\mathrm{c}}$ & $1.05 \pm 0.12^{\mathrm{c}}$ \\
\hline Protein & $16.44 \pm 0.20^{\mathrm{a}}$ & $14.35 \pm 0.10^{\mathrm{b}}$ & $12.94 \pm 0.15^{\mathrm{c}}$ & $8.34 \pm 0.24^{\mathrm{d}}$ & $14.54 \pm 0.17^{\mathrm{a}}$ & $13.43 \pm 0.12^{\mathrm{b}}$ & $10.70 \pm 0.24^{\mathrm{c}}$ & $8.30 \pm 0.14^{\mathrm{d}}$ \\
\hline Fat & $15.40 \pm 0.21^{\mathrm{a}}$ & $13.60 \pm 0.16^{\mathrm{b}}$ & $11.40 \pm 0.14^{\mathrm{c}}$ & $1.50 \pm 0.35^{\mathrm{d}}$ & $15.16 \pm 0.20^{\mathrm{a}}$ & $13.75 \pm 0.16^{\mathrm{b}}$ & $11.20 \pm 0.20^{\mathrm{c}}$ & $3.34 \pm 0.24^{\mathrm{d}}$ \\
\hline Crude fiber & $4.08 \pm 0.41^{\mathrm{a}}$ & $3.05 \pm 0.21^{\mathrm{b}}$ & $2.80 \pm 0.26^{\mathrm{c}}$ & $2.15 \pm 0.38^{\mathrm{d}}$ & $3.06 \pm 0.08^{\mathrm{a}}$ & $2.04 \pm 0.05^{\mathrm{b}}$ & $1.02 \pm 0.03^{\mathrm{c}}$ & $1.20 \pm 0.02^{\mathrm{d}}$ \\
\hline Carbohydrate & $51.06 \pm 0.32^{\mathrm{a}}$ & $59.15 \pm 0.17^{\mathrm{b}}$ & $64.33 \pm 0.26^{\mathrm{c}}$ & $81.75 \pm 0.35^{\mathrm{d}}$ & $63.69 \pm 0.14^{\mathrm{a}}$ & $67.94 \pm 0.20^{\mathrm{b}}$ & $74.66 \pm 0.26^{\mathrm{c}}$ & $85.00 \pm 0.46^{\mathrm{d}}$ \\
\hline
\end{tabular}

Means in the same row with different letters are significantly different $(\mathrm{P}<0.05)$.

\subsection{Vitamin}

Table 2 shows the results of the vitamin C and Vitamin A content of the samples. Vitamin C was not detected in the control samples of bread and cake. The highest value for vitamin $\mathrm{A}$ and $\mathrm{C}$ content of the samples were $4.83 \pm 0.17 \mathrm{mg} / 100 \mathrm{~g}$ and $10.07 \pm 0.07 \mathrm{mg} / 100 \mathrm{~g}$ respectively for bread and $6.15 \pm 0.21 \mathrm{mg} / 100 \mathrm{~g}$ and $8.47 \pm 0.30 \mathrm{mg} / 100 \mathrm{~g}$ for cakes, which were recorded for $70 / 30$ ratio each. The control samples for both bread and cake had the least values for vitamin A and vitamin C.

Table 2. Vitamin A and C content of bread and cake produced from wheat/beniseed composite flour ( $\mathrm{mg} / 100 \mathrm{~g})$

\begin{tabular}{lll}
\hline Sample & Vitamin A & Vitamin C \\
\hline Bread & & \\
$70 / 30$ & $4.83 \pm 0.17^{\mathrm{a}}$ & $10.07 \pm 0.21^{\mathrm{a}}$ \\
$80 / 20$ & $4.36 \pm 0.12^{\mathrm{b}}$ & $7.29 \pm 0.14^{\mathrm{b}}$ \\
$90 / 10$ & $2.45 \pm 0.12^{\mathrm{c}}$ & $4.56 \pm 0.27^{\mathrm{c}}$ \\
Control & $\mathrm{ND}$ & $\mathrm{ND}$ \\
\hline Cake & \\
$70 / 30$ & $6.15 \pm 0.21^{\mathrm{a}}$ & $8.47 \pm 0.30^{\mathrm{a}}$ \\
$80 / 20$ & $4.76 \pm 0.31^{\mathrm{b}}$ & $5.35 \pm 0.22^{\mathrm{b}}$ \\
$90 / 10$ & $3.44 \pm 0.26^{\mathrm{c}}$ & $3.64 \pm 0.31^{\mathrm{c}}$ \\
Control & $\mathrm{ND}$ & $\mathrm{ND}$ \\
\hline
\end{tabular}

Values are means of triplicate determinations and values with different superscript within row are statistically different $(\mathrm{P}<0.05)$. 


\subsection{Minerals}

Table 3 shows the mineral contents of the samples. Sodium contents of the samples ranged from $100.20 \pm 0.20 \mathrm{mg} / 100 \mathrm{~g}$ to $159.63 \pm 0.40 \mathrm{mg} / 100 \mathrm{~g}$ for bread, and from $110.20 \pm 0.20 \mathrm{mg} / 100 \mathrm{~g}$ to $130.47 \pm 0.40 \mathrm{mg} / 100 \mathrm{~g}$ for cake. The potassium value was highest in the samples and the values ranged from $200.05 \pm 0.30 \mathrm{mg} / 100 \mathrm{~g}$ to $584.53 \pm 0.40 \mathrm{mg} / 100 \mathrm{~g}$ for bread, and from $250.30 \pm 0.04 \mathrm{mg} / 100 \mathrm{~g}$ to $584.20 \pm 05 \mathrm{mg} / 100 \mathrm{~g}$ for cake. Calcium content of the samples were the least with values ranging from $36.10 \pm 0.02 \mathrm{mg} / 100 \mathrm{~g}$ to $140.25 \pm 0.30 \mathrm{mg} / 100 \mathrm{~g}$ (bread) and from $41.40 \pm 0.03 \mathrm{mg} / 100 \mathrm{~g}$ to $209.38 \pm 0.20 \mathrm{mg} / 100 \mathrm{~g}$. In all the mineral elements, baked products produced from $70 / 30$ ratio had higher $(\mathrm{P}<0.05)$ values, while the control samples had lower values $(\mathrm{P}<0.05)$.

Table 3. Mineral composition of wheat /beniseed flour bread and cake samples (mg/100g)

\begin{tabular}{lllllllll}
\hline & \multicolumn{3}{c}{ Bread } & & \multicolumn{3}{c}{ Cake } \\
Mineral & Control & $90 / 10$ & $80 / 20$ & $70 / 30$ & Control & $90 / 10$ & $80 / 20$ & 70.30 \\
\hline Sodium & $100.20 \pm 0.20^{\mathrm{d}}$ & $119.77 \pm 0.40^{\mathrm{c}}$ & $137.75 \pm 0.30^{\mathrm{b}}$ & $159.63 \pm 0.40^{\mathrm{a}}$ & $110.20 \pm 0.20^{\mathrm{d}}$ & $117.82 \pm 0.20^{\mathrm{c}}$ & $125.64 \pm 0.20^{\mathrm{b}}$ & $130.47 \pm 0.40^{\mathrm{a}}$ \\
Potassium & $200.05 \pm 0.30^{\mathrm{d}}$ & $514.84 \pm 0.20^{\mathrm{c}}$ & $549.64 \pm 0.40^{\mathrm{b}}$ & $584.53 \pm 0.50^{\mathrm{a}}$ & $250.30 \pm 0.04^{\mathrm{d}}$ & $513.81 \pm 0.10^{\mathrm{c}}$ & $573.64 \pm 0.20^{\mathrm{b}}$ & $584.20 \pm 0.50^{\mathrm{a}}$ \\
Calcium & $36.10 \pm 0.02^{\mathrm{d}}$ & $107.42 \pm 0.20^{\mathrm{c}}$ & $128.82 \pm 0.40^{\mathrm{b}}$ & $140.25 \pm 0.30^{\mathrm{a}}$ & $41.40 \pm 0.03^{\mathrm{d}}$ & $113.83 \pm 0.30^{\mathrm{c}}$ & $181.60 \pm 0.40^{\mathrm{b}}$ & $209.38 \pm 0.20^{\mathrm{a}}$ \\
Magnesium & $170.30 \pm 0.04^{\mathrm{d}}$ & $192.10 \pm 0.30^{\mathrm{c}}$ & $213.89 \pm 0.05^{\mathrm{b}}$ & $235.69 \pm 0.40^{\mathrm{a}}$ & $180.35 \pm 0.04^{\mathrm{d}}$ & $185.76 \pm 0.40^{\mathrm{c}}$ & $191.53 \pm 0.30^{\mathrm{b}}$ & $207.29 \pm 0.50^{\mathrm{a}}$ \\
Phosphorus & $150.30 \pm 0.20^{\mathrm{d}}$ & $420.44 \pm 0.40^{\mathrm{c}}$ & $448.88 \pm 0.60^{\mathrm{c}}$ & $460.32 \pm 0.04^{\mathrm{a}}$ & $402.50 \pm 0.30^{\mathrm{d}}$ & $429.30 \pm 0.20^{\mathrm{c}}$ & $456.29 \pm 0.40^{\mathrm{b}}$ & $483.40 \pm 0.90^{\mathrm{a}}$ \\
\hline
\end{tabular}

Different superscript $(a, b, c \& d)$ within each row in the same group indicate significant $(\mathrm{P}<0.05)$ differences .

Values are means of triplicate determination.

\subsection{Antinutritional Factors}

The results of the antinutritional contents of the samples are shown in Table 4. The control samples had the highest values $(\mathrm{P}<0.05)$ for total oxalate and soluble oxalate. Total oxalate values ranged from $34.40 \pm 0.03 \mathrm{mg} / 100 \mathrm{~g}$ to $27.85 \pm 0.02 \mathrm{mg} / 100 \mathrm{~g}$ (bread) and from $32.03 \pm 0.3 \mathrm{mg} / 100 \mathrm{~g}$ to $22.13 \pm 0.01 \mathrm{mg} / 100 \mathrm{~g}$ (cake). Soluble oxalate levels ranged from $18.62 \pm 0.03 \mathrm{mg} / 100 \mathrm{~g}$ to $12.47 \pm 0.01 \mathrm{mg} / 100 \mathrm{~g}$ (bread) and from $19.70 \pm 0.01 \mathrm{mg} / 100 \mathrm{~g}$ to $11.20 \pm 0.10 \mathrm{mg} / 100 \mathrm{~g}$ (cake). The phytate content of the $70 / 30$ samples were within comparable range. The phytate content ranged from $0.08 \pm 0.01 \mathrm{mg} / 100 \mathrm{~g}$ (control) to $0.16 \pm 0.01 \mathrm{mg} / 100 \mathrm{~g}(70 / 30)$ for bread samples. The values of the cake samples ranged from $0.06 \pm 0.01 \mathrm{mg} / 100 \mathrm{~g}$ (control) to 0.14 $\pm 0.10 \mathrm{mg} / 100 \mathrm{~g}(70 / 30)$ samples. The tannin content value was highest for $70 / 30$ for both bread and cake samples. Both controls had the least tannin values.

Table 4. Antinutritional contents of wheat/beniseed composite flour bread and cake samples ( $\mathrm{mg} / 100 \mathrm{~g})$

\begin{tabular}{lllllllll}
\hline & \multicolumn{3}{c}{ Bread } & \multicolumn{3}{c}{ Cake } \\
parameters & Control & $90 / 10$ & $80 / 20$ & $70 / 30$ & Control & $90 / 10$ & $80 / 20$ & $70 / 30$ \\
\hline Total Oxalate & $34.40 \pm 0.3^{\mathrm{a}}$ & $31.47 \pm 0.01^{\mathrm{a}}$ & $29.59 \pm 0.01^{\mathrm{b}}$ & $27.85 \pm 0.02^{\mathrm{b}}$ & $32.03 \pm 0.03^{\mathrm{a}}$ & $28.18 \pm 0.01^{\mathrm{b}}$ & $26.72 \pm 0.02^{\mathrm{c}}$ & $22.13 \pm 0.01^{\mathrm{d}}$ \\
Soluble Oxalate & $18.62 \pm 0.03^{\mathrm{a}}$ & $16.20 \pm 0.10^{\mathrm{b}}$ & $14.20 \pm 0.02^{\mathrm{c}}$ & $12.47 \pm 0.01^{\mathrm{d}}$ & $19.70+0.01^{\mathrm{a}}$ & $15.84 \pm 0.02^{\mathrm{b}}$ & $13.75 \pm 0.01^{\mathrm{c}}$ & $11.20 \pm 0.10^{\mathrm{d}}$ \\
Phytate & $0.08+0.01^{\mathrm{a}}$ & $0.10 \pm 0.01^{\mathrm{a}}$ & $0.12 \pm 0.02^{\mathrm{a}}$ & $0.16 \pm 0.01^{\mathrm{a}}$ & $0.06+0.01^{\mathrm{a}}$ & $0.11 \pm 0.02^{\mathrm{a}}$ & $0.12 \pm 0.01^{\mathrm{a}}$ & $0.14 \pm 0.10^{\mathrm{a}}$ \\
Tannins & $0.48+0.02^{\mathrm{c}}$ & $0.45 \pm 0.01^{\mathrm{c}}$ & $0.52 \pm 0.10^{\mathrm{b}}$ & $0.61 \pm 0.02^{\mathrm{a}}$ & $0.30 \pm 0.02^{\mathrm{d}}$ & $0.40 \pm 0.02^{\mathrm{c}}$ & $0.47 \pm 0.01^{\mathrm{b}}$ & $0.54 \pm 0.01^{\mathrm{a}}$ \\
\hline
\end{tabular}

Different superscript $(\mathrm{a}, \mathrm{b}, \mathrm{c} \& \mathrm{~d})$ within each row in the same group indicate significant $(\mathrm{P}<0.05)$ differences

Values are means of triplicate determination.

\subsection{Sensory Evaluation}

The panelists mean ratings for the samples is shown in Table 5. It was found that the taste score ranged from $5.3 \pm 0.50$ to $7.8 \pm 0.50$ (bread) and from $4.8 \pm 0.40$ to $8.0 \pm 0.50$ (cake). Color rating of bread ranged from $4.8 \pm 0.70$ to $9.4 \pm 1.0$ and from $5.2 \pm 055$ to $7.6 \pm 0.50$ for cake. There was no significant $(\mathrm{P}<0.05)$ difference between $70 / 30$ and $80 / 20$ samples in flavor ratings. The least rating was $6.1 \pm 1.9(70 / 30)$ while the highest was $4.7 \pm 0.30$ (control). The values for the cake samples ranged from $4.5 \pm 2.1$ to $5.4 \pm 2.80$ for texture. The samples of bread \& 
cake from 90.10 composite had the best rating of overall acceptability with values of $4.8 \pm 0.70$ and $4.4 \pm 1.2$ respectively.

Table 5. Mean panelist ratings for bread and cake samples produced from wheat/beniseed composite flour

\begin{tabular}{lllllllll}
\hline & \multicolumn{9}{c}{ Bread } & \multicolumn{4}{c}{ Cake } \\
Parameter & $70 / 30$ & $80 / 20$ & $90 / 10$ & Control & $70 / 30$ & $80 / 20$ & $90 / 10$ & Control \\
\hline Taste & $7.8 \pm 0.50^{\mathrm{a}}$ & $6.7 \pm 0.80^{\mathrm{b}}$ & $5.3 \pm 0.50^{\mathrm{c}}$ & $5.2 \pm 0.50^{\mathrm{c}}$ & $8.0 \pm 0.40^{\mathrm{a}}$ & $6.1 \pm 1.60^{\mathrm{b}}$ & $4.8 \pm 0.40^{\mathrm{C}}$ & $4.8 \pm 0.52^{\mathrm{c}}$ \\
Color & $9.4 \pm 1.00^{\mathrm{a}}$ & $5.6 \pm 1.00^{\mathrm{b}}$ & $5.0 \pm 0.80^{\mathrm{c}}$ & $48 \pm 0.70^{\mathrm{c}}$ & $7.6 \pm 0.50^{\mathrm{a}}$ & $5.60 \pm 1.80^{\mathrm{b}}$ & $5.4 \pm 1.72^{\mathrm{b}}$ & $5.2 \pm 0.55^{\mathrm{b}}$ \\
Flavor & $6.1 \pm 1.90^{\mathrm{a}}$ & $5.7 \pm 1.50^{\mathrm{a}}$ & $4.8 \pm 0.90^{\mathrm{b}}$ & $4.7 \pm 2.30^{\mathrm{b}}$ & $5.4 \pm 2.80^{\mathrm{a}}$ & $5.1 \pm 2.10^{\mathrm{a}}$ & $4.6 \pm 2.00^{\mathrm{b}}$ & $4.5 \pm 2.10^{\mathrm{b}}$ \\
Texture & $6.8 \pm 1.20^{\mathrm{a}}$ & $5.2 \pm 1.70^{\mathrm{b}}$ & $4.7 \pm 1.20^{\mathrm{c}}$ & $4.7 \pm 1.37^{\mathrm{c}}$ & $3.7 \pm 0.30^{\mathrm{a}}$ & $2.7 \pm 1.00^{\mathrm{b}}$ & $1.6 \pm 1.20^{\mathrm{c}}$ & $1.7 \pm 1.30^{\mathrm{c}}$ \\
Overall acceptability & $6.9 \pm 1.82^{\mathrm{a}}$ & $5.8 \pm 1.90^{\mathrm{b}}$ & $4.8 \pm 0.70^{\mathrm{c}}$ & $4.8 \pm 0.97^{\mathrm{c}}$ & $6.7 \pm 2.0^{\mathrm{a}}$ & $4.4 \pm 2.30^{\mathrm{b}}$ & $4.4 \pm 1.20^{\mathrm{b}}$ & $4.2 \pm 1.4^{\mathrm{b}}$ \\
\hline
\end{tabular}

Different superscript $(a, b, c \& d)$ within each row in the same group indicate significant $(\mathrm{P}<0.05)$ difference Values are means of triplicate determination.

\section{Discussion}

\subsection{Proximate Composition}

The moisture content of bread samples significantly $(\mathrm{P}<0.05)$ increased from $7.28 \pm 0.04 \%$ to $11.7 .09 \pm 0.02 \%$ with increase in the level of beniseed flour (10-30\%). Similar trend was observed for the cake samples, with increase in moisture content from $1.32 \pm 0.12 \%$ to $2.15 \pm 0.15 \%$. The increase in moisture content could be due to increasing protein level from increased beniseed addition. Proteins particularly from cereals have been noted to have high affinity for moisture and would absorb increasing amount of moisture if available (Jideani and Akingbala, 1993; Alabo 2006). However, this may have adverse effect on the quality attributes (Oyetoro et al., 2007). Ayo et al. (2010) also reported similar findings. The ash content of the bread and cake samples increased from $1.25 \pm 0.10 \%$ to $1.93 \pm 0.01 \%$ and from $1.10 \pm 0.04 \%$ to $1.40 \pm 0.14 \%$ respectively with increase in the proportion of beniseed. The values for the control samples of bread and cake samples were significantly $(\mathrm{P}<0.05)$ lower than the composite samples. This indicated that incorporation of beniseed may enhance the amount of mineral intake in the food product (Oyetoro et al., 2007), and as such would contribute appreciable dietary amounts of mineral. This result is in agreement with reports of Ayo et al. (2010) and Afolabi et al. (2004). The protein content of bread and cake samples indicated that $70 / 30$ percent sample had significantly $(\mathrm{P}<0.05)$ the highest values of $16.44 \pm 0.20 \%$ and $14.54 \pm 0.17 \%$ respectively. This is obviously due to increase in the proportion of beniseed. Similar findings was reported by earlier workers (Afalabi, 2001; Ayo et al., 2010). Alobo (2006) reported that the beniseed has a good balance of amino acids with a chemical score of $62 \%$ and a net protein utilization of $54 \%$. This indicates that consumption of these baked products produced from the composite flour would supply significant amount of protein to the body. The values obtained for the fat content of the bread and cake samples showed that $70 / 30$ percent samples had significantly $(\mathrm{P}<0.05)$ the highest values of $15.40 \pm 0.21 \%$ and $15.16 \pm 0.20 \%$, while $90 / 10$ percent sample had the least values among the composite samples. The progressive increase in the fat contents of the products may be attributable to addition of full fat beniseed flour, which is an oil seed. High fat content could impact negatively on the shelf stability of a product due to rancidity development. Ayo et al. (2010) reported a non significant difference in the fat content of defatted beniseed and Acha flour. Hence for better storage quality, defatting the oil seed before utilization may yield better result, if beniseed is to be used at higher substitution level. There was a significant difference $(\mathrm{P}<0.05)$ in the crude fibre content of composite bread and cake with the controls, which had the lowest values of $2.15 \pm 0.30 \%$ (bread) and $1.20 \pm 0.0 \%$ (cake). Crude fiber values showed that the 70/30 ratio for both bread and cake samples had significantly $(\mathrm{P}<0.05)$ the highest values, while the least crude fiber values were the control samples. High fiber is beneficial to the body, as it could help to maintain bowel integrity, lower blood cholesterol level, and control blood sugar level, hence consumption of these products would provide appreciable amount of fiber to the body for proper functioning of the digestive and excretory systems. The result showed that there was a significant difference $(\mathrm{P}<0.05)$ between all the samples in the carbohydrate values, where 90/10 ratios had the highest values of $64.33 \pm 0.26 \%$ (bread) and $74.66 \pm 0.26 \%$ (cake), while $70 / 30$ ratios had the least values of $51.06 \pm 0.32 \%$ (bread) and $63.69 \pm 0.14 \%$ (cake). The control samples had significantly higher $(\mathrm{P}<0.05)$ carbohydrate content with values of $81.75 \pm 0.35 \%$ and $85.00 \pm 0.46 \%$ respectively for bread and cake. 


\subsection{Vitamin}

There was a significant increase $(\mathrm{P}<0.05)$ in the vitamin $\mathrm{A}$ and $\mathrm{C}$ content of the samples with increasing beniseed level. Vitamin A and C activity were not detected in the control samples. The results indicated that 70/30 ratio had the highest vitamin A and C levels. The values for bread samples were $4.83 \pm 0.17 \mathrm{mg} / 100 \mathrm{~g}$ (vitamin A) and $10.07 \pm 0.21 \mathrm{mg} / 100 \mathrm{~g}$ (vitamin C), while the values for cake samples were $6.15 \pm 0.21 \mathrm{mg} / 100 \mathrm{~g}$ (vitamin $\mathrm{A}$ ) and $8.47 \pm 0.30 \mathrm{mg} / 100 \mathrm{~g}$ (vitamin C) . The higher values of vitamin A for the cake sample may be from the eggs used in the cake mix. Vitamin A and C levels in these products are significant as a result of the beneficial roles of these vitamins in the body. Vitamin A plays an important role in vision, bone growth, reproduction, cell division and cell differentiation (Institute of Medicine;2001, Ross and Gardness, 1994), and regulate the immune system, which helps to fight off infections by making white blood cells that destroy harmful bacteria and viruses (Ross, 1999), and Harbige (1996). Vitamin A also helps in the healthy lining of the eyes, respiratory, urinary and intestinal tract (Semba 1999). The health benefit of vitamin $C$ include protection against immune system deficiencies, cardiovascular diseases, prenatal health problems, eye disease and even skin wrinkling (Zelman, 2011).

\subsection{Mineral Elements}

The mineral contents of the samples were significantly $(\mathrm{P}<0.05)$ improved. Sodium, Potassium, calcium magnesium and phosphorus levels increased by $59.63 \%, 192.24 \%, 288.50 \%, 38.40 \%$ and $206.27 \%$ respectively in the bread samples produced from 70.30 ratio compared to the control. In the cake samples, $18.39 \%$ (sodium), 133.40\% (Potassium), 405.75\% (Calcium), 14.94\% (Magnesium) and 20.10\% (Phosphorus) increases were recorded in the 70.30 ratio. In both baked products, calcium content was significantly $(\mathrm{P}<0.05)$ the highest. Understandably, the higher mineral contents of the experimental samples could be attributed to the increasing proportions of beniseed, which contains high mineral elements. Hence, bread and cakes samples produced from the composite would supply appreciable amounts of minerals, required for various metabolic functions. Weaver \& Heaney (2006) reported that calcium is a micronutrient essential to health \& well being, which performs diverse biological function in the human body. It serves as a second messenger for nearly every biological process, stabilizes many protein and in deficient amounts is associated with a large number of disease and discovers. The Food and Nutrition Board (FNB, 1980) recommended a dietary allowance of 360mg and 1200mg calcium for infants and young adults. A deficiency in calcium could lead to ricket or osteoporosis.

\subsection{Antinutritional Factors}

Significant $(\mathrm{P}<0.05)$ differences in the levels of the anti-nutrients between bread and cake samples were observed. Generally, higher levels of antinutrients were found in the bread samples compared to those in the cakes. Total oxalate decreased significantly $(\mathrm{P}<0.05)$ with increase in beniseed substitution, with the lowest values for 70/30. This reduction may be due to nutrient-nutrient interaction with increasing levels of beniseed. Consumption of high levels of oxalate causes corrosive gastroenteritis, shock, low plasma calcium, high plasma oxalates and renal damage (kelsay, 1985). The level of phytate and tannins content significantly increased $(\mathrm{P}<0.05)$ with increase in beniseed substitution for both bread and cake. However, the levels of phytate and tannin in the baked products were low as to have anti effect to the nutrients. High levels of phytates in human nutrition are toxic and limit the bioavailability of calcium, magnesium, iron and phosphorus by the formation of insoluble compounds with the minerals (Aletor and Omodara, 1994). Tannins are known to inhibit the activities of digestive enzymes (Jambunathan \& Singh, 1981). Tannin-protein complexes are insoluble and this decreases the protein digestibility (Carnovale et al., 1991). The results showed that the concentrations of anti-nutrients in the composite flour were below toxic levels.

\subsection{Sensory Evaluation}

There was a significant decrease $(\mathrm{P}<0.05)$ in the sensory ratings of bread and cake with increase in beniseed level. However, the rating of taste, color, flavor, texture and overall acceptability for $90 / 10$ and control for bread and cake samples were not significant. The samples produced from 70/30 ratio were rated least by the panelists. This may be due to by-products of reaction between carbohydrate and protein which developed undesirable sensory notes. The addition of $10 \%$ beniseed produced acceptable bread of comparable quality with the control in all the sensory indicators, while addition of beniseed up to $20 \%$ was accepted for cake production.

\section{Conclusion}

In conclusion, $10 \%$ and $20 \%$ beniseed flour substitution rate for wheat flour produced an acceptable bread and cake respectively with high nutritive quality compared to whole wheat flour. School lunch snacks based on beniseed and wheat flour would provide a healthy snack and also protect against obesity and diabetes in both 
children and adults. Consequently, production of cakes and breads of different kinds from $10-20 \%$ beniseed composite with wheat flour would provide an extra-nutrition especially for growing children.

\section{References}

Abou-Garbia, H. A., Shehata, A. A. Y., \& Shahidi, F. (2000). Effect of Processing on oxidative stability and lipid classes of Sesame oil. Food Res Int, 33, 331-340. http:/dx.doi.org/10.1016/so963-9969(00)00052.1

Abu-Jdajil, B., Al-Malah, K., \& Asoud, H. (2002). Rheological Characterization of Milled Sesame (Tahineh). Food Hydrocolloids, 16, 55-61. http:/dx.doi.org/10.1016/S0268-005X(01) 00040-6

Addison, W. L. T. (1982). The Uses of Sodium Bromide and Potassium Bromide in cases of Arterial Hypertension which are Amendable to Potassium Chloride. Can. Med. Assoc. J., 18, 281-285.

Afolabi, W. A. O., Oguntona, C. R. B., \& Fakunmoju, B. B. (2001). Acceptability and Chemical Composition of Bread from Beniseed Composite flour. Journal of Nutrition and Food Sciences, 31(6), 310-313.

Akaninwor J. O., \& Okechukwu, P. N. (2004). Comparative nutrient \& anti-nutrient levels in commercial \& formulated weaning mixtures. Biokemistry, 16(1), 15-21.

Akanji, A. M., Ologhobo, A. D., Emiola, I. A., \& Oladunjoye, I. O. (2003). Effect of raw and differently processed Sesame seeds and performance and nutrition utilization of broiler chickens. Proceedings of the 28th Annual Conference of the Nigerian Society of Animal Production, 23, 184-186.

Aletor, V. A., \& Omodara, O.A.(1994). Studies of some leguminous brow plants with particular reference to their proximate, mineral and some endogenous anti-nutritional constituents. Anim Feed Sci Technol, 46, 343-348.

Alobo, A. P. (2006). Effect of Sesame seed on millet biscuit. Journal of Plant Foods for Human Nutrition, 64, 21-27.

Alobo, A. P. (2001). Effect of Sesame Seed flour on millet biscuit characteristics. Plant Food Hum. Nutri., 56, 195-202. http:/dx.doi.org/10.1023/A.1011168724195

AOAC. (1990). Association of Official Analytical Chemists. Official Method of Analysis (15th ed). Washington D. C. USA.

AOAC. (2005). Official methods of Analysis, 16th ed Association of official Analytical chemistry Arlington V. A. 806-842.

Ayo, J. A., Ikuomola, D. S., Esan, Y. O., Onuoha, O. G., Ayo. V. A., \& Ekele, V. (2010). Effect of added defatted beniseed on the quality of Acha based biscuits. Continental J. Food Sci. \& Tech, 4, 7-13

Blood, D. C., \& Henderson, J. A., (1974). Veterinery Medicine, 4th edn. Bailher Tindal London, 84-80.

Carnovale, E., Lugaro, E., \& Marconi, E. (1991). Protein Quality \& antinutritional factors in wild \& cultivated species of vigna spp. Plant Foods for Hum. Nutri, 41(1), 11-20. http://dx.doi.org/10.1007/BF62196377

Conney, R. V., Custer, L. T., Okinaka, L., \& Franke, A. A. (2001). Effects of Dietary Sesame Seeds on Plasma Tocopherol levels. Nutrition and Cancer, 39, 66-71. http://dx.doi.org/10.1207/S15327914nc391_9

Day, R. A., \& Underwood, A. I. (1986). Quantitative Analysis, 5th ed. Prentice \& Hall Publication, London, P. 701.

Eneobong, H. N. (2001). Eating Right: A Nutrition Guide. The University of Calabar Press, Calabar, Nigeria. Food \& Nutrition Board (FNB, 1980). Recommended Dietary Allowances. U. S. A.

Harbige, L. S. (1996) . Nutrition and Immunity with emphasis on infection and autoimmune disease. Nutria Health, 285-312.

Huo, Y. H. (1996). Bailey's Industrial oil and fat products. 5th edn. Wiley Inter-Science Publishers, London.

Institute of medicine. (2001). Food \& Nutrition Board. Dietary reference intakes for vitamin A, K, Arsenic, Boron, Chromium, copper, iodine, iron, manganese, molybdenum, Nickel, Silicon, Vanadium and Zinc. National Academy Press, Washington DC.

Jambunathan, R., \& Singhu, (1981). Grain quality of Pigeon. In proceeding of International workshop on Pigeon Pear, Vol. 1 ICRISAT, Hyderabad, Andra Pradesh, 15-19.

Jideani A. I., \& Akingbala, J. O. (1993). Some Physiochemical of Acha (Digitaria exiusstaph) and Ibuns (Digitaria Inunia staph) grains. Journal of Food Science Agri, 63, 369-374. http://dx.doi.org/10.1002/jsfa.2740630317 
Kelsay, J. L. (1985). Effect of oxalic acid on calcium bioavailability in: Kies C (ed). Nutritional Bioavailability of calcium. Washington, D. C. Am. Chem. Soc, 105-116.

Kirk, R. S., \& Sawyer, R. (1991). Pearsons composition \& Analysis of food. 9th ed. Longmans Scientific \& Technical, 223-246.

Larmond, E. (1977). Methods of Sensory Evaluation of Food. Food Research Institutes, Central Exp. Farm, Ottawa, Canada.

Lehninger, L. A. (1985). Principal of Biochemistry. Worth Publishers Inc. New York, 659-660.

Logan A. G. (2006). Dietary sodium Inpake and its Relation to human Health: A Summary of the Evidence Am Coll. Nutri., 25(3), 165-169.

Mac Gregor, G. A. (2008). Beneficial effects of potassium on human health. Physiol plant, 133(4), 25-35. http://dx.doi.org/10.1111/j.1399-3054.2007.01033.x

Mc Cane, R. A., \& Widdowson, E. M. (1953). Phytin in Human Nutrition Biochem J., 29, 2694-2699.

National Research Council. (1980). Recommended Dietary Allowances U. S. A.

Nickerson, J. T. R., \& Ronsivalli, C. J. (1980). Cereal grains in: Elementary Food Science, 2nd Edition. Avi Publishing Co. West Port, 19.

Nkama, I., \& Gbenyi, D. I. (2001). The effects of malting of millet \& sorghum on the residue phytate and poly-phenols in "dakura", a Nigerian cereal/legume snack food. Nig. Trop. J Agri, 3, 270-271.

Oke, O. L. (1960). Chemical Studies on Some Nigerian Foodstuff-Lafun. W. J. Biol. Applied Chemistry, 8(3), 53-56.

Oyetoro, A. O., Adesola, S. O., Kuyoro, A. A. (2007). Development of "kokori" with maize- soyabean and maize -groundnut blends. Proceedings of $31^{\text {st }}$ Annual Conference and General Meeting of Nigerian Institute of Food science and Technology.

Rosenthal, G. A., \& Janzen, D. H. (1979). Herbivores: Their Interaction with Plant Metabolites. Academic Press, New York.

Ross, A. C. (1999). Vitamin A and retinoids In: Modern nutrition in Health and Diseases. 9th Edition (edited) by Shils ME, Olson J, Shike M, Ross AC). Lippincoh Williams and Wilkin, New York, pp. 305-27.

Ross, A. C., \& Gardner, E. M. (1994). The function of vitamin A in cellular growth and differentiation and its roles during pregnancy and lactation. Adv Exp. Med. Biol., 182-200, 352.

Semba, R. D. (1999). The role of vitamin A and related retinols in immune functions. Nutri Rev, 56, 538-48.

Urbano, G., Lopez, J., Hernandez, J., Fernandez, Moreu, M. C., Frias, J., Diaz Pollan, C., Prodano, M., \& VidalVelverde, (1995). Nutritional assessment of raw, heated and germainaked lentils. J. Agric Food Chem., 1871-1877. http:/dx.doi.org/10.1021/jf 00055a022

Van de Poel, A. F. (1990). Effect of processing on anti-nutritional factors and protein nutritional value of dry Beans. Animal Feed Science and Technology, 2, 197-208.

Weaver, C. M., \& Heaney, R. P. (2006). Calcium in Human Health. Humana Press Inc. Totowa New Jersey. http://dx.doi.org/10.1007/978-1-59259-961-5

Zelman, (2011). Healthy eating a Diet. Retrieved June 19, 2011, form www.lifeclinic.com/focus 